\title{
Urgenda: the Final Judgment of the Dutch Supreme Court
}

\author{
C.W. (Chris) Backes \\ Professor of Environmental and Planning Law, Utrecht Center for Water, \\ Oceans and Sustainability Law (UCwOSL), Utrecht, The Netherlands \\ c.w.backes@uu.nl
}

G.A. (Gerrit) van der Veen

Professor of Environmental Law, University of Groningen, Groningen, The Netherlands

G.A.van.der.Veen@rug.nl

\begin{abstract}
The final verdict to the Urgenda case provided by the Dutch Supreme Court has been called a victory in the fight to limit climate change and a milestone in public interest litigation, at least in the Netherlands. As a consequence, the Dutch state will have to reduce GHG-emissions by $25 \%$ compared with 1990 at the end of 2020 . The judgment has attracted widespread acclaim for being 'courageous' and exploring unknown legal territory. However, a closer look at the reasoning of the Court of Appeal and the Supreme Court still leaves many questions, which are address in this manuscript.
\end{abstract}

\section{Keywords}

climate change - Urgenda - tort law - public interest litigation 
The Urgenda judgment may already be the best known Dutch court ruling ever, ${ }^{1}$ and it is well known to the readers of this journal. ${ }^{2}$ It has been called a victory in the fight to limit climate change and a milestone in public interest litigation, at least in the Netherlands. As a consequence of this ruling, the Dutch state will have to reduce GHG-emissions by $25 \%$ compared with 1990 at the end of 2020. The judgment has attracted widespread acclaim for being 'courageous' and being supported by compelling reasons. ${ }^{3}$ However, a closer look at the reasoning of the Court of Appeal and the Supreme Court still leaves many questions, which we will address in this manuscript after a short introduction of the Supreme Court's ruling.

\section{The Reasoning of the Supreme Court}

As the Dutch Supreme Court is a court of cassation, its judgment has to be read in conjunction with the judgment of the Court of Appeal. The Court of Appeal affirmed the lower District Court's judgment, albeit on different grounds. ${ }^{4}$ According to the Supreme Court, the Court of Appeal correctly based its judgment on the obligation of the State to protect its residents' right to life (Article 2 of the European Convention on Human Rights - ECHR) and right to family life (Article 8 ECHR). Under Dutch civil law (Section 3:305a Dutch Civil Code (DCC), a representative organisation can rely on these articles in a collective action. The ruling focused on the rights of current inhabitants of the Netherlands. Hence, it did not deal with the protection of future generations or people living elsewhere (paragraphs 2.2.2 and 2.3.2). Referring to the European Court

1 Supreme Court of the Netherlands, 20 December 2019, ECLI:NL:HR:2019:2006, English translation ECLI:NL:HR:2019:2007. This articles builds on our annotation to the judgment in $\mathrm{AB}$ Rechtspraak Bestuursrecht 2020/24.

2 See in particular, B. Wegener, Urgenda - World Rescue by Court Order? JEEPL, 2019, 16(2), pp. 125-147; L. Krämer, Climate Change, Human Rights and Access to Justice, JEEPL, 2019, 16(1), pp. 21-34; A.-S. Tabau and C. Cournil, New Perspectives for Climate Justice: District Court of The Hague, 24 June 2015, Urgenda Foundation versus the Netherlands, JEEPL, 2015, 12(3-4), pp. 221-240; and L. Bergkamp, A Dutch Court's 'Revolutionary' Climate Policy Judgment: The Perversion of Judicial Power, the State's Duties of Care, and Science, JEEPL, 2015, 12(3-4), pp. 241-263.

3 See J. Spier, note under the decision in NJ (Nederlandse Jurisprudentie) 2020/41.

4 See Gerrit van der Veen and Kars de Graaf, Climate litigation, climate act and climate agreement in the Netherlands, an update, in: Martha M. Roggenkamp and Catherine Banet (eds.), European Energy Law Report volume XIII, Intersentia 2020, pp. 457-469. 
of Human Rights' (ECtHR) case law, the Supreme Court held that appropriate measures have to be taken when there is a real threat to the lives and wellbeing of individuals. According to the Supreme Court, this also applies to environmental threats that might only occur in the long term. Also, these threats can be 'real and immediate' as long as the risk in question is directly threatening the persons involved (paragraph 5.3.3). Due to the real threat of climate change, there is a serious risk that the current generation of inhabitants of the Netherlands will be confronted with loss of life or a disruption of family life or both, the court reasoned. It therefore follows from Articles 2 and $8 \mathrm{ECHR}$ that the State has a duty to protect residents from this real threat.

The second question the court dealt with is what this responsibility means in the global context. Here, the court developed the notion of a fair share of the global responsibility. A country cannot 'duck' its responsibility to take measures by arguing that, compared with the rest of the world, its own emissions are relatively limited in scope and that a reduction of its own emissions would have no or very little impact on a global scale. If we accept such reasoning, noone can be held responsible and the rights deriving from Articles 2 and $8 \mathrm{ECHR}$ would not be protected effectively. Hence, the Dutch State is obliged to reduce greenhouse gas emissions from its territory in proportion to its share of the responsibility (paragraph 5.7.5 ff).

This leaves the third question: What is the least the State needs to do in order to fulfil 'its share' of the responsibility. In answering this question, the Supreme Court referred to a chart in one of the 2007 IPCC reports, which mentioned the figure of a decrease of the emissions of industrialized countries by $25 \%$ to $40 \%$ by 2020 to reduce global warming to an increase of maximum $2^{\circ} \mathrm{C}$. According to the court, there is overwhelming consensus on the urgent necessity for the Annex I countries to reduce greenhouse gas emissions by at least $25-40 \%$ in 2020. (paragraph 7.1 ff, more in particular paragraph 7.3.1). The Supreme Court added that there is broad consensus within climate science and the international community that the longer reduction measures are postponed, the more comprehensive and more expensive they will become. Furthermore, postponement creates a greater risk of an abrupt climate change occurring as the result of a tipping point being reached. Therefore, the State had the duty to explain that it would still contribute a fair share to the reduction of greenhouse gases if the reduction in 2020 were as little as $20 \%$ and would be accelerated after 2020 . The State failed to give adequate arguments that such a scenario would be feasible and sufficiently effective (paragraph 7.4.6.), especially because the State had previously adopted a strong stance, aiming for higher reduction figures and labelling any downwards adjustment as "implausible". The State is therefore under an obligation to reduce its greenhouse gas emissions by at least $25 \%$ by the end of 2020 . 
Quite obviously, the Supreme Court does not require that the failure to reduce GHG emissions by only $20 \%$ rather than $25 \%$ poses a danger to the lives or disruption of family life of the claimants or those they represent. Proving this causal link would be an impossible feat. Reducing emissions by at least $25 \%$ in 2020 , as ordered by the court, will not lead to any calculable decrease of any danger climate change may have for the inhabitants of the Netherlands. An emission reduction of $25 \%$ in the Netherlands will help set back the temperature rise by $0.000045^{\circ} \mathrm{C}$ and is therefore unlikely to help prevent floods, windstorms or droughts. The ability to overstep the causality requirement can be explained, in part, by the nature of the legal claim at issue. Rather than seeking compensation for any loss they had suffered, the claimants sought an order requiring the State to perform in a certain way. Under Dutch law, such claims for performance do not require proof of a full causal link between the unlawful action of the defendant and any (imminent and future) damage of the claimant. It is sufficient for the defendant to infringe a legal duty that protects the claimant's interests. ${ }^{5}$ This is one of the reasons why the courts quickly jumped on the question how to quantify the minimum reduction needed to constitute the 'fair share' of the Netherlands in the global efforts of fighting climate change. It could explain why Dutch courts of justice struggle much less than their counterparts in other countries ${ }^{6}$ with typical legal issues (predicting the loss/damage, causality, attribution) posed by climate actions based in human rights. As Articles 2 and 8 ECHR require the State to fight climate change in order to prevent harm, as, in the opinion of the court, a $25 \%$ reduction is the minimum fair share of the Netherlands in doing so and as Articles 2 and 8 ECHR protect the interests of the claimants, the State's failure to reduce emissions by this percentage at the least constitutes an unlawful act affecting the claimants.

5 See (in Dutch) C. Van Nispen, Het Rechterlijk Bevel en Verbod (diss. Leiden) Deventer: Kluwer 1978; Asser/Hartkamp \& Sieburgh 6-IV, nr. 153; T. Deurvorst, Groene Serie Onrechtmatige Daad, Deventer: Wolters Kluwer 2017, II.1.2.1; W. Th. Nuninga, Recht, plicht, bevel, verbod, NTBR 2018/21; Bleeker, Aansprakelijkheid voor klimaatschade: een driekoppige draak, NTвR 2018, pp. 4-11; en T. R. Bleeker, De knellende criteria van het rechterlijk bevel en verbod, in: F. van de Pol et al. (eds), Vijftig Weeffouten in het BW, Nijmegen: Ars Aequi Libri 2017.

6 See J. Setzer, L.C. Vanhala, Climate change litigation: A review of research on courts and litigants in climate governance, wiREs Climate Change 2019, p. 10. 
However, at least two aspects of this reasoning are susceptible to criticism. The first aspect is that there is no legal norm that requires the State to reduce its GHG emissions by $25 \%$ in 2020 . This point will be dealt with in sections 4 and 5 . The second aspect is the question whether there is in fact a real and immediate danger threatening the lives and homes of the claimants. That climate change can have huge detrimental effects, especially in many (poor) countries of the global south, is undisputed. Whether people living in the Netherlands right now will face serious risks within their lifetime is much less certain, however. Predicting what harm will befall the Netherlands due to climate change is very hard. The negative effects of climate change in the Netherlands appear quite manageable, even in worst case scenarios. ${ }^{7}$ The judgments pay very little attention to this issue.

\section{$4 \quad$ Legal Obligations and International Policy}

Every court, from the District Court upwards, established - correctly - that there are no legally binding norms obliging the State to reduce GHG emissions as demanded in Urgenda, ${ }^{8}$ neither in international law, EU law nor Dutch law. Rather, it was from a multitude of declarations of intent, appeals and statements that the courts inferred that the international community overwhelmingly agrees that "actually" more should be done than has been laid down in law. This political consensus that at least the Annex I countries should pursue a minimum emissions reduction of 25 to $40 \%$ until 2020 is then considered the lower limit of the positive obligations ensuing from Articles 2 and 8 ECHR in order to avert a real and immediate danger threatening the lives and health of Dutch citizens. This way, following a detour through Articles 2 and 8 ECHR, political, non-binding declarations and statements that the international community did not, and deliberately did not, lay down as mandatory have been elevated to the status of binding legal obligations. A remarkable process and result. Generally, and for good reason, a clear distinction is made in law between binding legal norms and various legally non-binding and unenforceable political statements. So it appears that Articles 2 and 8 ECHR have in some way

7 T.R. Bleeker, Aansprakelijkheid voor klimaatschade: een driekoppige draak, NTBR 2018(2), pp. 4-11, par. 2.2 referring to PBL, Effecten van klimaatverandering in Nederland, retrieved from https://www.pbl.nl/sites/default/files/downloads/773001034.pdf.

8 Supreme Court, 20 December 2019, ECLI:NL:HR:2019:2006, paragraph 6.2. 
managed to level out the distinction between legally binding obligations and (widely supported) international policy statements. ${ }^{9}$

The Supreme Court inferred the necessity to reduce emissions by "at least $25 \%$ " from the carbon budget calculated by the IPCC. This carbon budget is the total amount of carbon that can be emitted to stay within the objective of global warming not rising above 2 degrees Celsius. In the $\mathrm{AR}_{5}$ report, the IPCC concluded that if the concentration of greenhouse gases in the atmosphere stabilises at around $450 \mathrm{ppm}$ in the year 2100 , the chance that the global temperature increase would remain under $2^{\circ} \mathrm{C}$ was "likely", that is, higher than $66 \%$ (scenario RCP 2.6.)..$^{10}$ The $2^{\circ} \mathrm{C}$ maximum target is applicable law (Article 2 Paris Agreement). While this legally binding article is clearly couched in even more ambitious terms ("well below $2^{\circ} \mathrm{C}$ above pre-industrial levels and pursuing efforts to limit the temperature increase to $1.5^{\circ} \mathrm{C}$ above pre-industrial levels"), the maximum temperature increase was not laid down as a binding obligation but as the Agreement's aim (see Article 2(1), opening words, Paris Agreement $\left.{ }^{11}\right)$. In this light, the Supreme Court's representation of the Agreement ("The convention stipulates that global warming must be kept well below $2^{\circ} \mathrm{C}$ (paragraph 2.1(21)) is not quite correct. After all, rather than an obligatory outcome, this aim is merely a best-efforts obligation. ${ }^{2}$ It is important to note, however, that all countries that signed and then ratified the Paris Agreement did so committing to undertake efforts with a view to achieving the purpose of the Agreement; they did not commit to achieving the desired outcome, as is clear from Article 3. The Court of Appeal and the Supreme Court used a table from an

9 In this sense also Loth, Too big to trial? Lessons from the Urgenda case, Univ. Law Review 2018 (23), p. 336 who argues that this is a positive development.

10 IPCC, 2014: Climate Change 2014: Synthesis Report. Contribution of Working Groups I, II and III to the Fifth Assessment Report of the Intergovernmental Panel on Climate Change [Core Writing Team, R.K. Pachauri and L.A. Meyer (eds.)]. IPCc, Geneva, Switzerland, pp. 9 and 10.

11 Article 2(1) of the Paris Agreement reads: 'This Agreement, in enhancing the implementation of the Convention, including its objective, aims to strengthen the global response to the threat of climate change, in the context of sustainable development and efforts to eradicate poverty, including by: (a) Holding the increase in the global average temperature to well below $2^{\circ} \mathrm{C}$ above pre-industrial levels and pursuing efforts to limit the temperature increase to $1,5^{\circ} \mathrm{C}$ above pre-industrial levels, recognizing that this would significantly reduce the risks and impacts of climate change.' 
IPCC working group ${ }^{13}$ to determine which emission reductions are needed when in the Annex I countries (including the Netherlands) in order to achieve the $45^{\circ} \mathrm{ppm}$ carbon budget target. This table does mention the $25-40 \%$ reduction. However, the explanatory text preceding the table refers to different figures, mentioning a range between 10 and $40 \%$ (for all developed countries as a whole). This percentage range crops up and is explained at various other places in the report, unlike the $25-40 \%$ range, which only appears in the table specified, without receiving any explanation. ${ }^{14}$ In addition, the table does not reflect what the IPCC considers to be absolutely necessary; it rather reflects the very least the Annex I countries should contribute according to a fair and cost-effective effort-sharing between developed and developing countries. The Supreme Court does not address these - not unimportant - concerns and objections relating to the question what exactly it was that led the Supreme Court to infer that the IPCC believes a $25 \%$ reduction to be necessary, in spite of the State's argument to such effect. To avoid any misunderstanding: we do not doubt it makes perfect sense for the Netherlands to cut its emissions by at least $25 \%$ by the end of 2020 and that there are myriad arguments in favour of a moral obligation, from a global perspective, to do so, but that is not the same as a legal duty.

At many subsequent conventions, the $25-40 \%$ target was mentioned as the figure by which countries would need to reduce their emissions in order to achieve the $2^{\circ} \mathrm{C}$ aim..$^{15}$ Having thus gained international support, this reduction target is then, following a detour through Articles 2 and 8 ECHR, elevated to the status of legal norm. This way, broadly supported opinions on desirable

13 IPCC, 2007: Climate Change 2007: Mitigation. Contribution of Working Group III to the Fourth Assessment Report of the Intergovernmental Panel on Climate Change [B. Metz, O.R. Davidson, P.R. Bosch, R. Dave, L.A. Meyer (eds)], Cambridge University Press, Cambridge, United Kingdom and New York, NY, USA., p. 775.

14 The exact text (on p. 775) reads: 'For low and medium stabilization levels, developed countries as a group would need to reduce their emissions to below 1990 levels in 2020 (on the order of $-10 \%$ to $40 \%$ below 1990 levels for most of the considered regimes).' This is reiterated in the summary on p. 748 : 'For example, to limit the temperature increase to $2^{\circ} \mathrm{C}$ above pre-industrial levels, developed countries would need to reduce emissions in 2020 by $10-40 \%$ below 1990 levels and in 2050 by approximately. About this L. Meyer, Urgenda-vonnis ontbeert goede wetenschappelijke onderbouwing, Tijdschrift voor Milieu en Recht 2016 (36). Meyer was a member of the working group that drafted this part of the AR- 5 report.

15 See, for example, the 'Cancun pledges' made by the EU at the COP 16 2010: 40-95 https:// unfccc.int/topics/mitigation/workstreams/pre-2020-ambition/compilation-of-economy -wide-emission-reduction-targets-to-be-implemented-by-parties-included-in-annex-ito-the-convention. 
scenarios acquire a quasi-legal character. ${ }^{16}$ Even if we assume, as the Supreme Court does, that a $25-40 \%$ emissions cut would be the absolute minimum required to limit global warming to 2 degrees as agreed (virtually) unanimously by climate scientists, the legal consequences of that assumption are quite drastic. If governments and parliaments of countries which are party to the ECHR do not pursue a competent climate policy, failing to do the bare minimum climate scientists believe necessary, they can be forced, through the ECHR, to adhere to the scientific communis opinio after all.

This is a fundamental step. ${ }^{17}$ It may serve to produce part of the answer to the question how much democracy we can afford in our fight against global warming. Is it possible for a democratically responsible government and a democratically elected parliament to pursue a climate policy that scientists do not consider to be ambitious enough? This way, the results of scientific research, having gained broad acceptance, also gain legal momentum and drive. However, this goes at the expense of the latitude and influence that national democratically responsible and elected bodies wield. This, if we interpret it correctly, represents a marked shift in the global balance of power. A shift that may actually be commanded by the immense threat posed by the effects of global warming, but a shift to the judiciary from the democratic domain nonetheless. Governments and national parliaments do not have the liberty to take - or fail to take - measures where this constitutes a real and immediate threat to the lives and the rights to family life of the many. The decision space of the democratically elected bodies ends where the right to life and the right to private and family life are under considerable threat and where the measures necessary to avert this threat are not taken. That is just, as the case law of the ECtHR time and again confirms. ${ }^{18}$ Former decisions by the ECtHR, however, concerned very immediate dangers in specific locations to individuals or limited groups of citizens, there being a direct causal link between the measures to be taken by the authorities and the - avoidable - damage those individuals or groups could suffer. None of this is present in the Urgenda case.

16 See, in agreement, S. Boysen, Entgrenzt- pluralistisch - reflexiv - polyzentrisch kontestiert: Das Transnationale im transnationalen Klimaschutzrecht, zUR 2018, p. 648 and, critical, T. Voland, Wäre die 'Urgenda-Entscheidung' auch im deutschen Recht zu erwarten?, NvWZ 2019, p. 120.

17 For an overview of the literature on climate litigation based on human rights, the criticism it has drawn, and the legal obstacles steamrolled by the Dutch Supreme Court: J. Setzer, L.C. Vanhala, Climate change litigation: A review of research on courts and litigants in climate governance, WIREs Climate Change 2019, 1 ff., in particular par. 3.4.

18 For an overview of the case-law of the ECtHR on environmental cases see the fact sheet of the court 'Environment', which can be downloaded from the site of the ECtHR, https:// www.echr.coe.int/Documents/FS_Environment_ENG.pdf, lastly reviewed 27 April 2020. 
It is impossible to relate even the damage potentially inflicted on the inhabitants of the Netherlands many years into the future to that lack of liberty. The point the Supreme Court therefore appears to be arguing - differently from the ECtHR in its current case law ${ }^{19}$ - is not so much the State's obligation to avert actual threats to the current inhabitants of the Netherlands as much as it is about State's obligation to do its "minimal fair share" in combating a global threat. It is all but certain that the purpose and the function of Articles 2 and $8 \mathrm{ECHR}$ is to compel States to act in accordance with what in international political declarations is considered a necessary national ${ }^{20}$ contribution towards the solution of a global environmental issue. ${ }^{21}$ As for the Netherlands, that discussion is now closed. Obviously, this does not by any length mean that the Supreme Court's interpretation is correct or will be adopted by other signatories to the ECHR. That is something that will have to be awaited. As the Court of Appeal did not follow the new procedure of protocol 16 to the ECHR and failed to seek the ECtHR's advice, we will, alas, never know what their view is. The Court of Appeal and the Supreme Court arrived at their judgments by sailing into uncharted waters and applying Articles 2 and 8 ECHR to types of disputes and legal questions that have never been dealt with before, by the ECtHR or any national court for that matter. ${ }^{22}$ Definitely a factor shaping the law. Leijten has already referred to it as a "revolutionary human rights case". ${ }^{23}$ Only time will tell whether this newly developed law will hold up internationally.

\section{EU Law Related Aspects}

We are of the opinion that the EU law related aspects of the case have been given (too) little attention, again. We have to limit this section to indicating two aspects.

19 Supreme Court 20 December 2019, ECLI:NL:HR:2019:2006, para. 6.3.

20 We leave out of account the fact that the standards of international law and the policy statements, such as the preambles to the cop Statements, always address the Annex I countries or the EU as a whole, not the Netherlands as a separate party or State. The fact that within the EU - rightly or wrongly - a legally binding division of efforts has been established in which the Dutch contribution is lower than the European average (16\% vs $20 \%$ ) is also disregarded as being irrelevant.

21 Likewise critical is O. Spijkers, Urgenda tegen de Staat der Nederlanden: aan wiens kant staat de Nederlandse burger eigenljk?, AAe 2019, p. 191ff.

22 See also the analyses of O. Spijkers, Urgenda tegen de Staat der Nederlanden: aan wiens kant staat de Nederlandse burger eigenljk?, AAe 2019, p. $191 \mathrm{ff}$. and A.E.M. Leijten, De Urgenda-zaak als mensenrechtelijke proeftuin?, AV\&S 2019 (10), pp. 50-55.

23 A E.M. Leijten, De Urgenda-zaak als mensenrechtelijke proeftuin?, AV\&S 2019 (10), pp. $5^{0-55}$. 
First, the decision means that not only the State of the Netherlands has acted in "evident" (see, for instance, paragraphs 6.3 and 8.3.4.) violation of international law, but that the EU has done this as well. The EU set the $20 \%$ reduction obligation for 2020 , rather than the $25-40 \%$ emissions cut that is the "absolute minimum" and "evidently" necessary. Thus, the decision is a rough wake-up call for the EU and the Dutch government and parliament alike. As this concerns the interpretation of a number of international treaties and conventions, including mixed ones in areas where the EU acted as the regulatory institution, the question arises whether - in view of the fact that the Supreme Court has opted for an interpretation which in our view warrants no other conclusion than that the $\mathrm{EU}$, too, is in breach of its international law obligations the court should have referred to the EU Court of Justice for a preliminary ruling on the validity of various EU law related norms. As Articles 2 and $8 \mathrm{ECHR}$ are the basis for the Supreme Court's decision, the answer to the question whether there would have been an obligation to refer to the Court of Justice is not so simple. Merely stating that this is about national targets and that EU law does not bar national law from taking a more radical route and therefore has no relevance to the issue is not, in our view, an adequate answer. Since the General Court recently ruled out the possibility for EU citizens to bring the EU to court for its climate policy, ${ }^{24}$ the Urgenda case was for a long time the only case that offered the option of asking the European court to speak out about the EU's international climate obligations. However, also an opposite view has been advanced, which is that the Supreme Court based its decision on Articles 2 and 8 ECHR directly and used the UN Climate Convention and related agreements only to fill in the positive obligations under those documents, thus applying the obligations binding the State of the Netherlands as a signatory to the ECHR. The Netherlands is subject to an autonomous obligation - meaning, separate from EU law obligations - arising from that convention. According to some, this allows for the argument that the Supreme Court did not judge on any obligations of the EU and EU law. ${ }^{25}$

The second EU law aspect is related to the question as to how the obligation to cut emissions by at least $25 \%$ can be met. Any additional reductions are for the most part for the account of companies subject to mandatory participation in the ETS, such as coal-fired power plants (which would have to be shut down). If a measure of this kind is devised - at likely very high cost - in such a way that the emission rights covering the emissions from these plants are barred from

\footnotetext{
24 General Court 8 May 2019, Case T-330/18, Kingdom of the Netherlands and Others v. European Commission [2019]; ECLI:EU:T:2019:324. 
the market, this may actually result in a small emissions reduction until the end of the current trading period, late 2020. This cannot be said for the trading period after 2020, however. Closing down the Dutch coal-fired power plants will not lower the ETS emissions ceiling. The only effect that such an expensive measure would likely have is for the prices of emissions rights to drop, in turn reducing the pressure on the ETS participants to implement measures that would effectively lower their emissions. As a result, complying with the Supreme Court decision would have the opposite effect of what was originally intended. The Supreme Court has nonetheless shoved this "waterbed effect" aside, arguing - irrelevantly, in our opinion - that other EU countries have their own responsibility to cut $\mathrm{CO}_{2}$ emissions as much as possible. Be that as it may, it does not change the fact that measures resulting in a mandatory reduction in emissions for companies subject to participation in the ETS have no long-term effect on the actual emissions of greenhouse gases as long as the emissions ceiling is not adjusted. ${ }^{26}$ As far as we can tell, this is not altered by the recent modification of the ETS by means of Directive 2018/401/EU, part of which specifically targets power plants. In implementing the decision, the authorities need to guard against taking expensive measures that will only result in compliance - on paper - with the operative part of the decision but that have no actual effect on global greenhouse gas emissions.

The Urgenda Decision as Supplement to and Translation into Reality of the Paris Agreement

Unlike the Kyoto Protocol, the Paris Agreement does not incorporate any binding reduction targets. A protocol setting concrete and binding reduction targets has made way for a Treaty with a single, generally endorsed target ("well below 2 degrees"), the freedom for the signatories to translate that into national policy, and a focus on the process. The need to attach nationally determined contributions (NDCs) to achieving the well-below-2-degrees target and to discuss in UNFCC context whether these contributions suffice ${ }^{27}$ has set in motion a process of constant catering to the public agenda and debate, which

26 About this: L. Squintani, M. Holwerda, \& K.J.De Graaf, Regulating greenhouse gas emissions from EU ETs, in: M. Peeters e.a. (eds), Climate Law in EU Member States, 2012, p. 85 et seq.

27 For more on the state of affairs (contributions do not suffice), see: UNEP, The Emissions Gap Report 2019, downloadable here: https://wedocs.unep.org/bitstream/handle/20.500 $.11822 / 30797 /$ EGR2019.pdf?sequence $=1 \&$ isAllowed $=y$. 
is open to all stakeholders. ${ }^{28}$ In this debate, science has a strong, institutionalised and self-assured voice. The outcome of this debate may play a major part in the national struggle for a sound climate policy, a struggle that may involve the courts. Some scientists consider this a clear phenomenon of the development from a multi-level ${ }^{29}$ legal order with a clear hierarchy of standards into a multidimensional governance with the differences between legal and non-legal standards becoming blurred. ${ }^{30}$ Many have bemoaned the lack of any concrete national reduction obligations as a key weakness of the Paris Agreement, while others characterise the enormous growth of global climate litigation as the logical consequence of the failure of international treaty law. ${ }^{31}$ That may be true, but it is far from certain whether the architecture of the Paris Agreement will eventually prove as sound as or perhaps even better than that of the Kyoto Protocol. The national debates about the (minimum) national contributions to achieving the global objectives set out in the Paris Agreement are an important element of that architecture. Normally, these debates are conducted in national parliaments. However, governments ruling with parliamentary majorities have a much narrower "interests horizon", spanning a few years at most, which does not sit well with the focus on action needed to have long-term effects. Judges are not bothered by interest horizons. ${ }^{32}$ In that sense, the Urgenda ruling is a highly important, perhaps essential, supplement to the instruments provided in the Paris Agreement. ${ }^{33}$

28 For the conceptual difference between Kyoto and Paris, see also S. Boysen, Entgrenztpluralistisch - reflexiv - polyzentrisch - kontestiert: Das Transnationale im transnationalen Klimaschutzrecht, zUR 2018, p. $648 \mathrm{ff}$. and R. Falkner, The Paris Agreement and the New Logic of International Climate Politics, International Affairs 2016 (92) p. 1107 et seq.

29 Also referred to as polycentric, see, for example, M. Loth, Eenheid in gelaagdheid, AAe 2019, p. 335 et seq. and S. Boysen, supra note 16 at p. 648 et seq.

30 For an overview of scientific literature on this theme, see: J. Setzer, L.C. Vanhala, supra note 6, p. 1 et seq. in particular par. 3.1. See also S. Boysen supra note 16 at p. 648 et seq. and M. Loth, supra note 29, at p. 335 et seq. Eenheid in gelaagdheid, AAe 2019, p. $335 f f$.

31 For an overview of literature, see J. Setzer, L.C. Vanhala, supra note 6, p. 1 et seq. in particular par. 3.1 Climate change litigation: A review of research on courts and litigants in climate governance, WIREs Climate Change 2019, $1 \mathrm{ff}$., in particular par. 3.1.

32 In a similar vein, also, for example, A. Graser, Vermeintliche Fesseln der Demokratie: Warum die Klimaklagen ein vielversprechender Weg sind, zUR 2019, p. 272.

33 See also E.R. de Jong, Urgenda en de beoordeling van macro-argumenten, MvV 2019, p. 133, who argues that the function of Urgenda, and liability law of the authorities in general, has a place in the transformation of a trias politica system of checks and balances into a system of prods and pleas. 


\section{A Flash in the Pan or the Dawn of a New Era of Judicial Activism?}

The question is whether rulings like Urgenda can now be expected to be handed down in other areas of law, environmental and otherwise. An example could be found in the area of air quality law. Observing the wHo limit values in, for example, the Netherlands would save hundreds of lives, with immediate results. The WHO's average air quality guidelines for particulate matter (PM1o), for example, are twice as strict as the EU's legally binding limit values. Even when it comes to the highly dangerous very fine particulate matter (PM2.5), the international scientific community recommends that values should be kept at about $50 \%$ below EU standards. Air pollution is the largest risk to people's health in Europe, according to the European Environmental Agency (EEA), accounting for approximately 400,000 premature deaths across Europe.$^{34}$ If one follows the line of reasoning set out by the Supreme Court in its Urgenda decision, it is arguable that the State has not adequately fulfilled its obligations to protect the lives and health of its citizens and is failing to do the minimum - according to the communis opinio among scientists worldwide - it can be expected to do. There is widespread global agreement on the wHo guidelines. Even more clearly so than is the case for the greenhouse gas emissions reductions, the EU's limit values have their roots in a political balancing act, weighing economic and financial interests against what would be the absolute minimum for public health reasons. In these circumstances, the State could at the very least be expected to draft a policy plan aimed at improving air quality fast and achieving the wHO values within a few years. That would, after all, save thousands of lives a year or, in other words, increase average life expectancy, for example in the Netherlands by six months, ${ }^{35}$ not counting the beneficial effects on many other health complaints. And there are non-disproportionate measures that would allow the State to achieve this objective. ${ }^{36}$ In the case of air pollution - contrary to greenhouse gases - there is a direct - and undisputed - causal connection between those measures and a reduction in the number of deaths and health complaints and a higher life expectancy. The court would have less difficulty handing down an order against the State in comparison with the Urgenda case.

The only remaining reason to differentiate between the climate-case and the air quality-case would be that the climate problem is an issue of such

\footnotetext{
$34 \quad$ EEA, Air Quality Report 2019, Copenhagen 2019, p. 13 and 14.

35 According to EU Directive 2008/50/EG, the limit value is 20 microgram (annual average), the wHO limit value is 10 microgram.

36 See RIVM, GGD-richtlijn medische milieukunde: luchtkwaliteit en gezondheid, Bilthoven 2018, Par. 5 .
} 
exceptional urgency that it requires judges to hand down exceptional rulings. The upshot there would be that the courts could allow authorities more leeway to shape environmental policy in all cases except those relating to the climate. That would be a highly problematic strategy. Taking it to extremes: Does the risk of sea levels rising by, for example slightly more than $2 \mathrm{~m}$ in the Netherlands by 2100 present a more exceptional and serious threat than the premature deaths of several thousands of Dutch citizens, year in, year out, right now? And is it right to ask our judges to consider such issues? Why is it fine for our authorities and legislator to give economic reasons for setting the air quality limit values at twice the values scientists all over the world deem necessary, but at the same time is not okay for them to set the minimally necessary greenhouse gas emissions reductions at a value one-fifth lower than scientists deem necessary? There is a distinct possibility that before long the Supreme Court, or courts in other countries, will be asked to apply the Urgenda line of reasoning to other files in which more resolute action by legislator and government alike could save human lives and prevent health hazards. Examples are not hard to find. The question will be where the Supreme Court, and other courts, will draw the line regarding the rights arising from Articles 2 and 8 ECHR.

\section{9}

\section{Conclusion}

The judgement emphasises that the Netherlands as a State has been guilty of serious misconduct. The Dutch government and Parliament have made downwards adjustments to earlier reduction targets, without good reason, thereby avoiding their responsibilities. Through 2017, greenhouse gas emissions were cut by just $13 \%$ over 1990 levels. What's more, the bulk of the reduction can be attributed to reductions in emissions of greenhouse gases other than carbon dioxide (which, by the way, has very little effect on the consequences of global warming; the various effects of the greenhouse gases, such as decomposition rate, are factored into the conversion in $\mathrm{CO}_{2}$ equivalents). In fact, emissions of carbon dioxide in the Netherlands increased, slightly, by approx. 2 megatons $!^{37}$ So despite all those statements, promises and undertakings and although the scope of the climate issue has been known for about 40 to 50 years now, the Dutch government has barely made baby steps in combating the rise of $\mathrm{CO}_{2}$ emissions and working towards reducing them. With a mere $7.4 \%$ of energy consumption coming from renewable energy sources, the Netherlands ranks lowest among all EU countries and is set to fail to meet its European obligations 
for 2020, despite stepping up its efforts. We put these disappointing figures before you, not to blame the Dutch government and parliament, but because they may have been a factor in causing the Urgenda judgment, which makes them important in construing that judgment. Given this background, the Supreme Court's decision is understandable, and from a political and social perspective it is an invaluable contribution to the development of Dutch climate policy. Those are the merits of Urgenda and of the brave judges in all instances of that case. Unlike many of our colleagues, ${ }^{38}$ we expressly continue to doubt the legal merits of the judges' reasoning, but the decision has superseded the relevance of our doubts. The outcome is clear, the decision must be enforced. However, our doubts may be of importance in estimating the significance of the decision for other countries and other issues being litigated.

38 The Urgenda judgment has proved controversial, nationally and internationally. See, for example, B. Wegener, Urgenda - World Rescue by Court Order? JEE PL 16 (2019), p. 125ff. A reply can be found, from the hands of A. Graser, Vermeintliche Fesseln der Demokratie: Warum die Klimaklagen ein vielversprechender Weg sind, zUR 2019, p. 271 ff. and G. Winter, G. Armando Carvalho et al ii versus Europäische Union, zUR 2019, 259 ff. See also footnote 2 . 